\title{
The Production Efficiency on Edible Birds' Nest: The Case Study in Gua Musang and Johor Bahru, Malaysia
}

Fatin Farazh Ya'acob, Mohamad Zaim Isamail, Mohamad Faizal Ramli, Muhammad Majid, Nurkhairany Amyra Mokhtar, Basri Badyalina, Rabiatul Munirah Alpandi

To Link this Article: http://dx.doi.org/10.6007/IJARBSS/v12-i1/11643

DOI:10.6007/IJARBSS/v12-i1/11643

Received: 05 November 2021, Revised: 07 December 2021, Accepted: 24 December 2021

Published Online: 14 January 2022

In-Text Citation: (Ya'acob et al., 2022)

To Cite this Article: Ya'acob, F. F., Isamail, M. Z., Ramli, M. F., Majid, M., Mokhtar, N. A., Badyalina, B., \& Alpandi, R. M. (2022). The Production Efficiency on Edible Birds' Nest: The Case Study in Gua Musang and Johor Bahru, Malaysia. International Journal of Academic Research in Business and Social Sciences, 12(1), $449-461$.

\section{Copyright: (c) 2022 The Author(s)}

Published by Human Resource Management Academic Research Society (www.hrmars.com)

This article is published under the Creative Commons Attribution (CC BY 4.0) license. Anyone may reproduce, distribute, translate and create derivative works of this article (for both commercial and non0-commercial purposes), subject to full attribution to the original publication and authors. The full terms of this license may be seen at: http://creativecommons.org/licences/by/4.0/legalcode

Vol. 12, No. 1, 2022, Pg. $449-461$

Full Terms \& Conditions of access and use can be found at http://hrmars.com/index.php/pages/detail/publication-ethics 


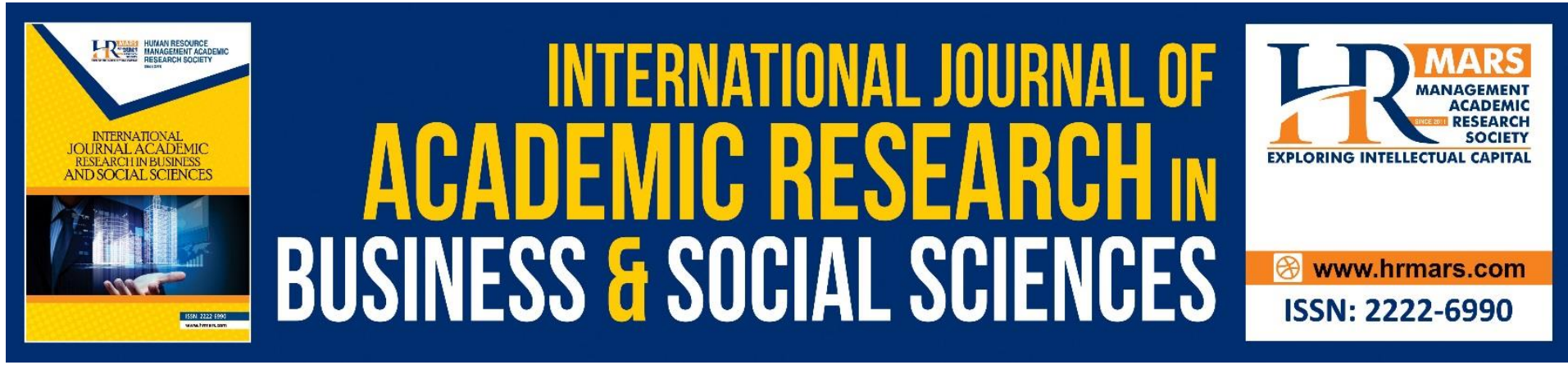

\title{
The Production Efficiency on Edible Birds' Nest: The Case Study in Gua Musang and Johor Bahru, Malaysia
}

\author{
Fatin Farazh Ya'acob \\ Fakulti Pengurusan dan Perniagaan, Universiti Teknologi MARA, Cawangan Johor, Kampus \\ Segamat. \\ Email: fatinfarazh@uitm.edu.my
}

\section{Mohamad Zaim Isamail}

Akademi Pengajian Islam Kontemporari, Universiti Teknologi MARA, Cawangan Johor, Kampus Segamat.

Email: mohamadzaim@uitm.edu.my

\author{
Mohamad Faizal Ramli, Muhammad Majid \\ Fakulti Pengurusan dan Perniagaan, Universiti Teknologi MARA, Cawangan Johor, Kampus \\ Segamat. \\ Email: faizalramli@uitm.edu.my,muhdmajid@uitm.edu.my
}

\begin{abstract}
Nurkhairany Amyra Mokhtar, Basri Badyalina
Fakulti Sains Komputer dan Matematik, Universiti Teknologi MARA Cawangan Johor, Kampus Segamat.

Email: nurkhairany@uitm.edu.my, basribdy@uitm.edu.my
\end{abstract}

\author{
Rabiatul Munirah Alpandi \\ School of Accounting \& Finance, Taylors University, Selangor, Malaysia \\ Email: munirah.alpandi@taylors.edu.my
}

\begin{abstract}
This study was commissioned to determine efficient swiftlet houses. The research draws attention to the fact that seventy percent of swiftlet houses in Malaysia failed to produce Edible Birdnest (EBN) efficiently even though the number of swiftlet houses increases every year due to highly demanded of EBN and encouragement from government. This industry has recorded an Economic Transformation Programme (ETP) as the government sees this industry can generate income for the Malaysian economy. By knowing the efficient swiftlet houses, it is then can be a benchmark to inefficient swiftlet houses. The production efficiency is necessary to step toward increasing the supply of EBN in order to fulfill the market demand. Thus, Data Envelopment Analysis (DEA) was used to model efficiencies. This paper also
\end{abstract}


performs a series of parametric and non-parametric univariate test (Mann-Whitney and Kruskal Walls) to assess the difference in the efficiency and productivity of swiftlet ranching. This study was conducted in Gua Musang and Johor Bahru, Malaysia. Results of data analysed show that the inefficiency of swiftlet houses in both districts come from the scale inefficiency. Even both districts have scale inefficiency, however, the scale inefficiency in Gua Musang is higher compared to Johor Bahru. Most of the ranchers in Gua Musang and Johor Bahru experience increasing economies of scale (IRS) due to being at less than the optimum size. This study recommended that swiftlet houses in Gua Musang must operate at the correct scale of operations. Gua Musang has a high potential to expand the EBN productivity more advanced due to environmental factors such as the abundance of forests, rivers and oil palm estates that attract more population of swiftlet in Gua Musang.

Keywords: DEA, Production Efficiency, Swiftlet.

\section{Introduction}

The efficiency of swiftlet ranchers is an interesting topic to economists concerned with the problems in developing countries. Since swiftlet ranching industry is a new industry in Malaysia yet it is important as compared to other major industries such as rubber, palm oil, oil and gas, timber, financial services and SMI manufacturing (Hameed, 2007). Malaysia is one of the largest producer of EBN with an increasing number of swiftlet houses. Under the 10th Malaysian Plan, the government targeted to achieve 100,000 swiftlet houses with a total production of RM5 billion worth of EBN. There is a strong likelihood for continuous growth of the swiftlet ranching industry in Malaysia over the next decade. Among the reasons are due to the continuous high international demand for EBN, highly profitable investment, and the continuous advancements being made in swiftlet ranching (Hameed, 2007).

Despite the rising number of swiftlet houses, it has been reported that more than seventy percent are failed (Alias et al., 2012). Failure in this context refers to swiftlet houses that are empty or with very few numbers of nests and swiftlet houses that are unable to lure enough birds. A successful swiftlet house could produce at least $1.36 \mathrm{~kg}$ of nests which is around one hundred and fifty nests after one year of operation (Lim, 2007). These above mentioned reasons could be the cause for investors being unable to breakeven on their investment at the expected time.

To be successful and produce an efficient production of EBN, the swiftlet ranching needs to be well planned and managed in term of internal design and construction of the house (Ibrahim et al., 2009). Besides that, number of floors, number of planks, square fit area and years of swiftlet house also can encourage efficient production of EBN (Laurentius, 2004). Thus it is important to measure efficiency of the above factors in order to make sure the output which is the production of EBN efficient. This is in line with Entry Point Project (EPP) aims to boost productivity of this industry by encouraging the establishment of new premises (Shahwahid \& Zulnaidah, 2012).

In this study, the objective in this study is twofold which are:

- First is to determine the efficiency ranchers and thus help to segregate efficient ranchers from inefficient. Besides that, these efficient swiftlet houses can be as a benchmark in order for others to have a successful swiftlet house.

- Second, as suggested by Banker \& Natarajan (2008), this paper also performs a series of 
parametric and non-parametric univariate test to assess the difference in the efficiency and productivity of swiftlet ranching in Gua Musang and Johor Bahru. Thus, by perform this, this study can capture which districts are relatively more productive and can be benchmark to improve productivity of EBN.

\section{Materials and Methods}

This objective employed by Data Envelopment Analysis (DEA) to determine the efficient ranchers of swiftlet house are based on productivity level of bird nest of each swiftlet house. The technical and scale efficiency of swiftlet house is analysed based on the production of EBN from different input and output sources. Besides that, this stage helps to identify the criteria for an efficient swiftlet house and can be considered as a benchmark in order for others to also be successful ranchers. The DEA method is used to gauge the total management efficiency in Johor Bahru and Gua Musang. In addition, the other efficiency concept, such as management efficiency (PTE) and size efficiency (SE) are also investigated at this stage in order to identify the total management efficiency level (TE). This study also employed parametric and non-parametric analysis in order to compare which area had better management (TE).

\section{Estimating Efficiency using DEA}

DEA is a methodology-based application of linear programming that was originated to measure performance efficiency of organization units called Decision Making Unit (DMUs) (Ramanathan, 2003). This technique aims to measure the efficiency of a DMU using the input resources available to generate a set of outputs (Charnes et al, 1978). The DMU in this study is the swiftlet ranch. The DEA method can isolate the production performance of individual DMUs instead of depicting the average DMU as often found in a parametric analysis. In other words, DEA can focus on the individual performance observations as represented by the optimization of each DMU. The difference is that parametric analysis focuses on the average and estimation of parameters that are associated with a single optimization statistical approach.

Since the DEA is used to measure the efficiency level of DMU, this study uses this method in the measurement of the total management of the swiftlet house (TE), management efficiency (PTE) and size of management efficiency (SE) in order to produce EBN at optimal levels. The output and inputs used are shown in Table 1 below.

Table 1: Output and Inputs of a Swiftlet House

\begin{tabular}{lll}
\hline Variable & Symbol & Variable Name \\
\hline Output & Y1 & EBN \\
Inputs & X1 & Size of swiftlet house \\
& X2 & Plank \\
& X3 & Level of storey \\
& X4 & Years of swiftlet house \\
\hline
\end{tabular}

Furthermore, according to Cooper et al, (2002), there is a rule that needs to be complied with in order to select the number of inputs and outputs. A rough rule of thumb is as follows:

$$
n \geq \max \{m \times s, 3(m+s)\}
$$


where: $\mathrm{n}=$ a number of DMUs

$m=$ a number of inputs

$s=$ a number of outputs

\section{Test on DEA}

The total management efficiency (TE), management efficiency (PTE) and size management efficiency (SE) of swiftlet houses in both districts are measured using the DEA method by applying the production approach. The data is tested by parametric (t-test) and nonparametric (Mann-Whitney [Wilcoxon] and Kruskal-Wallis) tests in order to compare which area is better in managing a swiftlet houses. For Mann-Whitney [Wilcoxon] and KruskalWallis, Banker (1993) and Banker \& Natarajan $(2004,2008)$ suggest that the DEA score is a consistent estimator. Thus, as suggested by Banker \& Natarajan (2008), this study proceed to test the null hypothesis (swiftlet ranching in Johor Bahru are relatively more efficient than swiftlet ranching in Gua Musang) against the alternative hypothesis (swiftlet ranching in Gua Musang are relatively more efficient than swiftlet ranching in Johor Bahru). For parametric, the t-test is employed. For non-parametric tests, this study employed the Mann-Whitney and Kruskal Walls to test the hypothesis. The Mann-Whitney $U$ test is similar to the Wilcoxon test, but can be used to compare multiple samples that aren't necessarily paired. The formal hypothesis that needs to be test is as follow:

HO: The swiftlet ranching in Johor Bahru are relatively more efficient than swiftlet ranching in Gua Musang.

Ha: The swiftlet ranching in Gua Musang are relatively more efficient than swiftlet ranching in Johor Bahru

\section{Data Collection}

The data collected includes the size of swiftlet house, number of planks, level of storey and years of bird house for inputs. For output, the yearly production of raw EBN was collected for each swiftlet house in Gua Musang and Johor Bahru.

\section{Result and Discussion Efficiency Score}

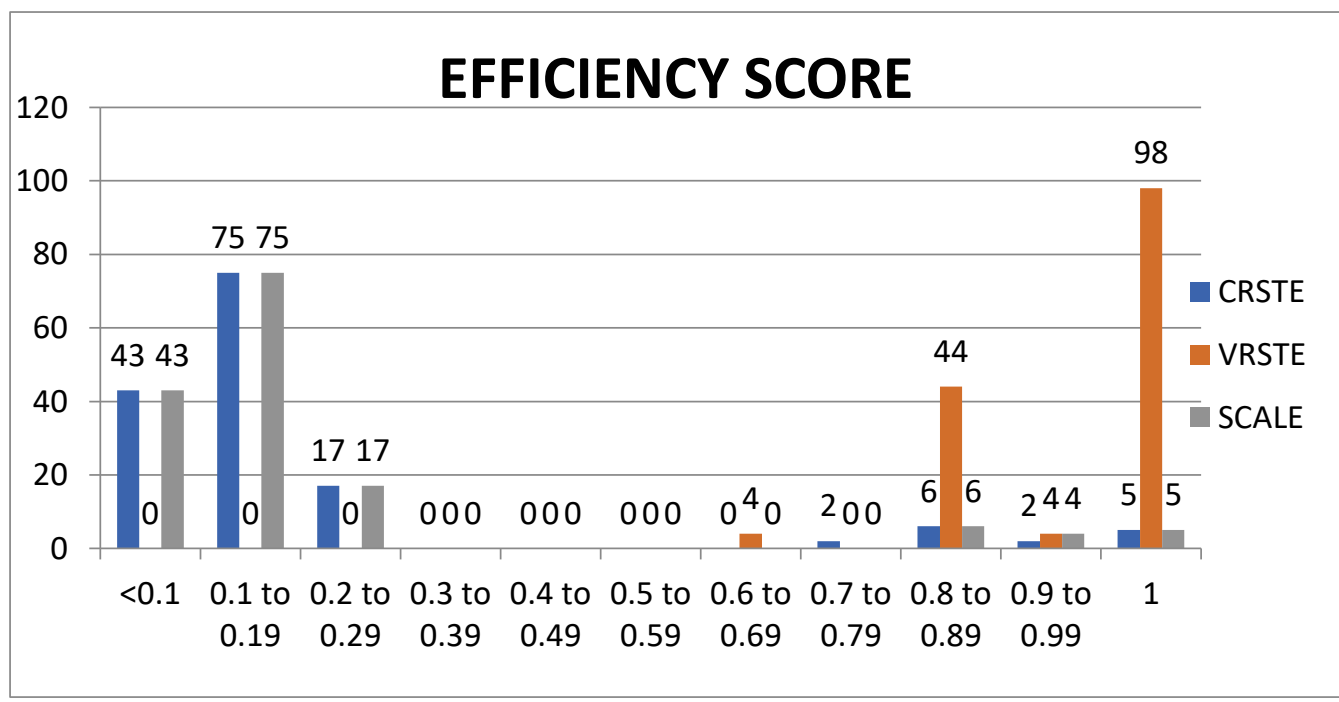

Figure 1: Efficiency score distribution of EBN ranchers in Gua Musang 
The result of input-oriented CCR and BBC models for Gua Musang are illustrated in Figure 1 above. Based on CCR result, 5 ranchers were relatively efficient with the technical efficiency score of one, and the remaining ranchers were inefficient. However, according to the result of BBC model, 98 ranchers had the pure technical efficiency of one. Four efficient ranchers in both CCR and BBC model and produce EBN at optimum scale size.

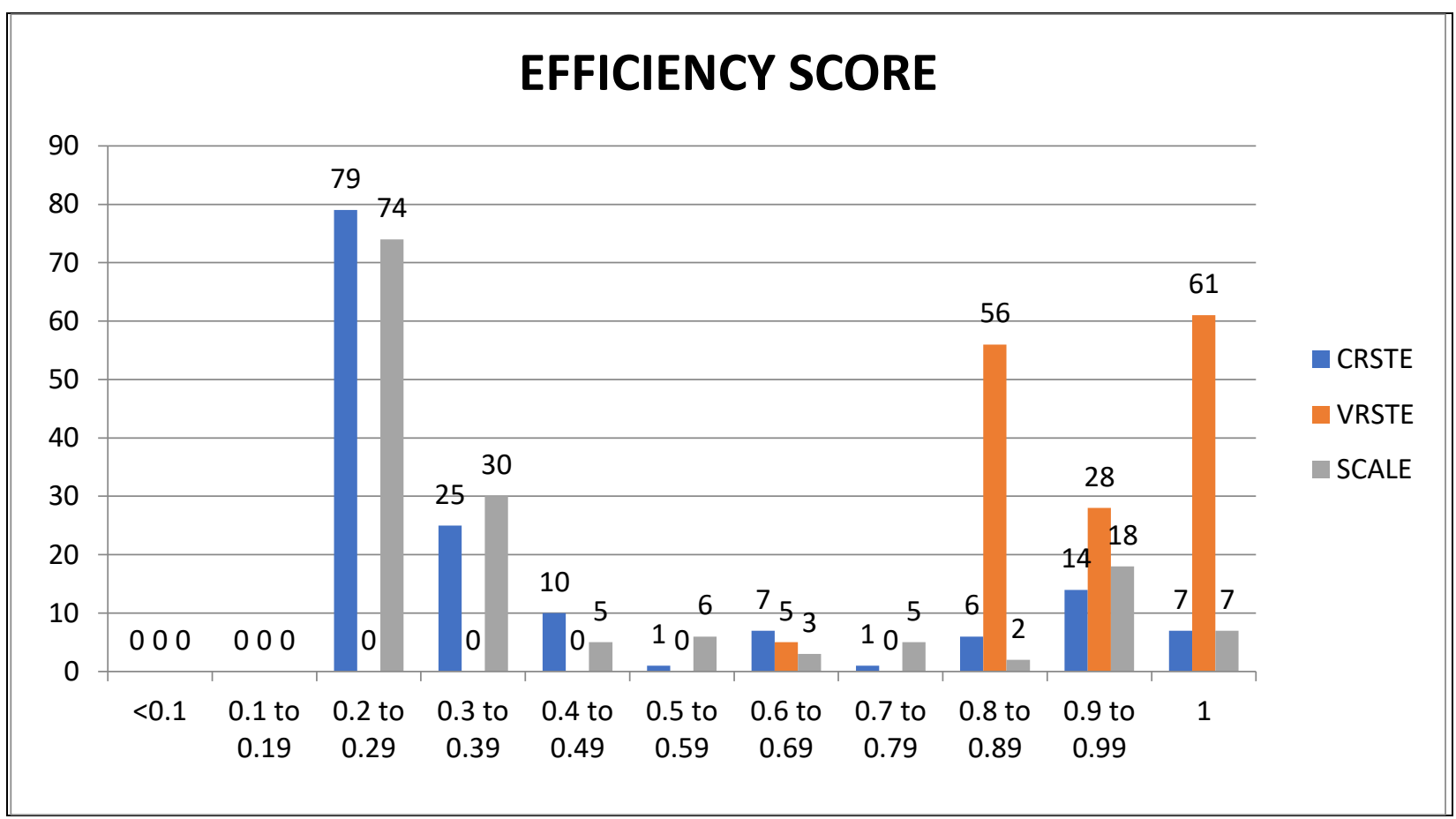

Figure 2: Efficiency score distribution of EBN ranchers in Johor Bahru

Based on Figure 2 above, 7 ranchers were relatively efficient with technical efficiency score of one and the remaining 143 ranchers were inefficient in Johor Bahru based on CCR result. Meanwhile for the $B B C$ model result, 61 ranchers had the pure technical efficiency of one. Thus, only 7 ranchers are efficient in both CCR and BBC models and produce EBN at optimum scale size.

\section{Efficiency Indices}

Summary statistical measure for the technical efficiency, pure technical efficiency and scale efficiency in Gua Musang are shown in Table 2 below. The average value of technical efficiency was 0.205 , pure technical efficiency was 0.947 and scale efficiency scores of ranchers was 0.215 . Technical efficiency varies from 0.082 to 1 with the standard deviation of 0.239 . The wide variation in the technical efficiency of ranchers indicates a substantial inefficiency between the EBN producers in the studied area.

Table 2: Efficiency indices of ranchers in birdnest production in Gua Musang

\begin{tabular}{|l|c|c|c|c|c|c|}
\hline Efficiency score & Min & Max & $\begin{array}{c}\text { Average } \\
\text { (efficient) }\end{array}$ & $\begin{array}{c}\text { Average } \\
\text { (inefficient) }\end{array}$ & $\begin{array}{c}\text { Percentage } \\
\text { (inefficient) }\end{array}$ & S.D \\
\hline Technical efficiency & 0.082 & 1 & 0.205 & 0.750 & 75.0 & 0.239 \\
\hline $\begin{array}{l}\text { Pure technical } \\
\text { efficiency }\end{array}$ & 0.667 & 1 & 0.947 & 0.053 & 5.3 & 0.079 \\
\hline Scale efficiency & 0.082 & 1 & 0.215 & 0.785 & 78.5 & 0.248 \\
\hline
\end{tabular}


Technical efficiency (TE) has two components which are pure technical efficiency (PTE) and scale efficiency (SE). PTE is defined as the utilization of pure management of the ranching while SE represents the size of the ranching. From the average value of technical efficiency (0.205), it explains that $20.5 \%$ efficient and the balance of $70.5 \%$ are inefficient. During the period under study, findings indicate that the inefficient of swiftlet house stems mainly from scale rather than pure technical as the percentage of average inefficient is higher than percentage of PTE inefficient, where it contribute $78.5 \%$ inefficient. If anything could be delved, the finding suggest that the swiftlet house has been relatively managerially efficient in controlling their management of all variables in swiftlet house, but have been operating at a relatively non-optimal scale of operations which mean they need to expand more their swiftlet house.

Table 3: Efficiency indices of ranchers in birdnest production in Johor Bahru

\begin{tabular}{|l|c|c|c|c|c|c|}
\hline Efficiency score & Min & Max & $\begin{array}{c}\text { Average } \\
\text { (efficient) }\end{array}$ & $\begin{array}{c}\text { Average } \\
\text { (inefficient) }\end{array}$ & $\begin{array}{c}\text { Percentage } \\
\text { (inefficient) }\end{array}$ & S.D \\
\hline $\begin{array}{l}\text { Technical } \\
\text { efficiency }\end{array}$ & 0.201 & 1 & 0.420 & 0.580 & 58.0 & 0.271 \\
\hline $\begin{array}{l}\text { Pure technical } \\
\text { efficiency }\end{array}$ & 0.669 & 1 & 0.928 & 0.072 & 7.2 & 0.080 \\
\hline Scale efficiency & 0.205 & 1 & 0.445 & 0.555 & 55.5 & 0.270 \\
\hline
\end{tabular}

For Johor Bahru, the efficiency indices of ranchers in birdnest production are shown in Table 3 above. The average value of technical efficiency was 0.420 , pure technical efficiency was 0.928 and scale efficiency scores of ranchers was 0.445 . Technical efficiency varies from 0.201 to 1 with the standard deviation of 0.271 . In Johor Bahru, the average technical efficiency indicates that $42 \%$ are efficient and another $58 \%$ are inefficient. The inefficient is come from scale which it contribute $55.5 \%$ inefficient rather than pure technical which only contribute $7.2 \%$ inefficient. The average scale efficiency of 0.445 implies that if all inefficient ranchers operate at optimum scale size, 55.5 percent inputs saving is possible without affecting the yield level.

This situation is similar with Gua Musang where the inefficient is comes from scale as the percentage inefficient of scale is higher than percentage of inefficient of pure technical. Even both districts have scale inefficiency, however the scale inefficiency in Gua Musang is higher compared to Johor Bahru. In general, the dominant effect of the scale inefficiency indicates that the majority of swiftlet houses in both districts have been operating at the incorrect scale of operations. Mostly of the rancher in Gua Musang and Johor Bahru experience increasing economies of scale (IRS) due to being at less than the optimum size. If they experience diseconomies of scale (DRS), this is due to being at more than the optimum size. Thus, decreasing or increasing the scale of production could result in efficiency. This study is in line with Nurshuhada et al (2015) which result found that one of the reasons inefficient eKasih swiftlet houses is the sizes. From the implementation of eKasih programme it shows that the size of swiftlet house played an important factor in order to make sure the swiftlet house is efficient. 


\section{Benchmarking}

In this study, benchmarking method was applied to rank the efficient ranchers. Identifying efficient ranchers and their dissemination will help to improve efficiency not only in the case of inefficient ranchers but also for some relatively efficient ones. The efficient ranchers obviously follow good operating practices. The results of ranking ten superior efficient ranchers for Gua Musang are presented in Table 4 while Table 5 is for Johor Bahru.

According to Table 4 below, rancher 4, 13, 9, 1 and 3have a highest TE score which is 1. As mentioned before TE is combination the effects of both pure technical efficiency and scale efficiency which represent the overall efficiency of rancher's swiftlet house. It means these ranchers efficient in the conversion of physical inputs into outputs relative to best practice. It indicates that these ranchers are really better than the other efficient ranchers. Therefore, the practices adopted by these ranchers can be selected for benchmarking and improving the performance of swiftlet house.

In other studied area (Johor Bahru), it shows that the ten superior ranchers that are have among the highest technical efficiency (TE). Based on Table 5 below, rancher number 6 , $40,35,23,39,30$ and 11 have the highest TE score compared to others. This finding suggest that in Johor Bahru, ranchers can follow the way these superior ranchers manage their swiftlet house in order to increase the EBN production.

Table 4: Ranking 10 superior efficient rancher in Gua Musang

\begin{tabular}{ccc}
\hline Rank & Firm & TE \\
\hline 1 & 4 & 1 \\
2 & 13 & 1 \\
3 & 9 & 1 \\
4 & 1 & 1 \\
5 & 3 & 1 \\
6 & 8 & 0.997 \\
7 & 10 & 0.958 \\
8 & 12 & 0.87 \\
9 & 2 & 0.859 \\
10 & 7 & 0.848 \\
\hline
\end{tabular}

Table 5: Ranking 10 superior efficient rancher in Johor Bahru

\begin{tabular}{ccc}
\hline Rank & Firm & TE \\
\hline 1 & 6 & 1 \\
2 & 40 & 1 \\
3 & 35 & 1 \\
4 & 23 & 1 \\
5 & 39 & 1 \\
6 & 30 & 1 \\
7 & 11 & 1 \\
8 & 7 & 0.993 \\
9 & 36 & 0.993 \\
10 & 37 & 0.972 \\
\hline
\end{tabular}


Overall, these findings indicated that the ten superior efficient of swiftlet house in Johor Bahru is more. In this context, when ranchers have higher technical efficiency it means that swiftlet house is efficient.

\section{Efficient use of input and output}

The quantity of sources input and output for ten most efficient ranchers and inefficient ranchers in Gua Musang are illustrated in Table 6. From table 5, the result indicates that inefficient ranchers are not using an efficient input to produce a better quantity of output. The size of swiftlet house is smaller compared to efficient swiftlet house. They also installed fewer planks in their swiftlet house thus, resulted in less production of EBN. They built a smaller swiftlet house, installed fewer planks and have less level of storey as compared to the efficient ranchers. Even though their swiftlet house already build for many year compared to efficient swiftlet house, however in term of scale, they need to big size of house to get yield more.

Table 6: Comparison yield and input use for efficient and inefficient ranchers in Gua Musang

\begin{tabular}{cccc}
\hline 10 superior efficient & infficient ranchers & Differences \\
ranchers & (B) & (A-B)/B *100 \\
\hline Items & $(\mathrm{A})$ & 24000 & -1591.67 \\
Size & 406000 & 1200 & -31.6667 \\
Plank & 1580 & 20 & -25 \\
Storey & 25 & 65 & 35.38462 \\
Year & 42 & 304 & -1243.42 \\
Yield & 4084 & & \\
\hline
\end{tabular}

Table 7: Comparison yield and input use for efficient and inefficient ranchers in Johor Bahru

\begin{tabular}{|c|c|c|c|}
\hline Items & $\begin{array}{l}10 \text { superior efficient } \\
\text { ranchers } \\
\text { (A) }\end{array}$ & $\begin{array}{l}10 \text { inefficient ranchers } \\
\text { (B) }\end{array}$ & $\begin{array}{c}\text { Differences } \\
(\mathrm{A}-\mathrm{B}) / \mathrm{B} * 100\end{array}$ \\
\hline Size & 442000 & 248000 & -78.2258 \\
\hline Plank & 1760 & 1240 & -41.9355 \\
\hline Storey & 25 & 20 & -25 \\
\hline Year & 54 & 77 & 29.87013 \\
\hline Yield & 2502 & 356 & -602.809 \\
\hline
\end{tabular}

For Johor Bahru, the same situation happened like in Gua Musang. From the result in Table 7, it shows that the inefficient ranchers are not efficient in using the input to produce a better quantity of output. In term of size of swiftlet house, number of plank and storey, their swiftlet house are deficient in comparison to those that are more efficient. They are not built a large size area and many planks compared to the efficient ranchers. Therefore, due to these deficiencies they produce less productivity of EBN compared to efficient swiftlet house even though they already build that swiftlet house longer than the efficient one.

There have no difference between Johor Bahru and Gua Musang as most of the inefficient ranchers in both districts have less input compared to the efficient ranchers even the swiftlet house is longer than efficient rancher. Overall, the inputs used for efficient 
swiftlet houses in Gua Musang is less compared to input used in Johor Bahru and the total yield in Gua Musang is higher compared to Johor Bahru. The inefficient is comes from scale for both districts, but the scale inefficiency in Gua Musang is higher compared to Johor Bahru even though the yield is higher than Johor Bahru. It indicates that, Gua Musang has a high potential to expand the EBN productivity more advanced even though they utilize less inputs than Johor Bahru. This can also due to environmental factors such as abundant of forests, rivers and oil palm estates that attract more population of swiftlet in Gua Musang.

\section{Univariate Test}

A series of parametric (t-test) and non-parametric (Mann-Whitney and Kruskal Walls) tests are performed to verify the difference between swiftlet ranching in Johor Bahru and GuaMusang's TE, PTE and SE levels. The results are given in Table 8 below.

Table 8: Summary of Parametric and Non-parametric Tests

\begin{tabular}{|c|c|c|c|c|c|c|}
\hline \multicolumn{7}{|c|}{ Test Group } \\
\hline & \multicolumn{2}{|c|}{ Parametric Test } & \multicolumn{4}{|c|}{ Non-parametric Tests } \\
\hline Individual Tests & \multicolumn{2}{|c|}{ t-test } & \multicolumn{2}{|c|}{$\begin{array}{c}\text { Mann-Whitney } \\
\text { [Wilcoxon Rank-Sum] } \\
\text { test }\end{array}$} & \multicolumn{2}{|c|}{$\begin{array}{c}\text { Kruskall-Wallis } \\
\text { Equality of Populations } \\
\text { test }\end{array}$} \\
\hline Hypothesis & & & Median & Median GM & & \\
\hline \multirow[t]{2}{*}{ Test Statistic } & \multicolumn{2}{|c|}{$t(\operatorname{Prb}>t)$} & \multicolumn{2}{|c|}{$z(\operatorname{Prb}>z)$} & \multicolumn{2}{|c|}{$X^{2}\left(\operatorname{Prb}>X^{2}\right)$} \\
\hline & Mean & $t$ & $\begin{array}{l}\text { Mean } \\
\text { Rank }\end{array}$ & $z$ & Mean Rank & $x^{2}$ \\
\hline \multicolumn{7}{|l|}{$\begin{array}{l}\text { Technical } \\
\text { Efficiency (TE) }\end{array}$} \\
\hline JB & 0.3920 & $6.293 * * *$ & 205.59 & $\begin{array}{l} \\
11.002 * * *\end{array}$ & 205.59 & $121.036 * * *$ \\
\hline GM & 0.2039 & & 95.41 & & 95.41 & \\
\hline \multicolumn{7}{|l|}{$\begin{array}{l}\text { Pure Technical } \\
\text { Efficiency (PTE) }\end{array}$} \\
\hline JB & 0.9284 & $-2.092^{*}$ & 136.56 & $-3.068 * *$ & 136.56 & $9.415 * *$ \\
\hline GM & 0.9477 & & 164.44 & & 164.44 & \\
\hline \multicolumn{7}{|l|}{$\begin{array}{l}\text { Scale Efficiency } \\
\text { (SE) }\end{array}$} \\
\hline JB & 0.4165 & $6.632 * * *$ & 208.27 & $\begin{array}{l}- \\
11.536 * * *\end{array}$ & 208.27 & $133.082 * * *$ \\
\hline GM & 0.2148 & & 92.73 & & 92.73 & \\
\hline
\end{tabular}

Note: ${ }^{* * *}, * *$ and $*$ indicate significant at the $0.01,0.05$ and 0.10 percent level respectively.

For parametric test, the result seem to suggest that ranchers in Johor Bahru have been more efficient compared to ranchers in Gua Musang as the mean for Johor Bahru is higher than Gua Musang $(0.390>0.2039)$. The ranchers in Johor Bahru were also found to be relatively scale efficient $(0.4165>0.2148)$. However, it found that it is pure technical inefficiency in Johor Bahru (0.9477>0.9284). For non-parametric test, both the Mann-Whitney and Kruskal Walls tests show that ranchers in Johor Bahru are more efficient compared with Gua Musang (205.59 > 95.41). Johor Bahru also found to be more scale efficient (208.27>92.73), but have been relatively pure technical inefficient (136.56< 164.44) 
compared to Gua Musang. Overall, all parametric and non-parametric test indicates that, ranchers in Johor Bahru is technical efficient and scale efficient however they are not pure technical efficient compared with Gua Musang. Thus, the null hypothesis is supported.

This study found that a more efficient swiftlet ranching is assumed to be well organized and has more capable management. The idea is that since there is room for improvement, the inefficient swiftlet house can make the efficient swiftlet house as a benchmark and this will lead to a transfer of better management quality to the unproductive swiftlet ranching. In addition, the government authorities such as DVS can get information from the efficient swiftlet ranching as a guide to be used as a SOP in the construction of a successful bird house.

\section{Conclusion}

The production efficiency of EBN ranching is important to make sure that the output of EBN production is efficient as the problems is the inefficient swiftlet house is more than 50 percent in Malaysia. This is in line with the EPP's aims to boost productivity of this industry by encouraging the establishment of new swiftlet houses. Thus, a non-parametric input-oriented DEA method was used to analyse technical efficiency of swiftlet ranchers where it consist of pure technical efficiency and scale efficiency. The data from 300 swiftlet houses are gathered for both districts (150 in Gua Musang and 150 in Johor Bahru). The results indicate inefficiency of swiftlet house in Johor Bahru and Gua Musang is comes from scale as the average number of scale efficiency is lower compared to average number of pure technical efficiency. In overall, the inefficient is comes from scale for both districts, but the scale inefficiency in Gua Musang is higher compared to Johor Bahru even though the yield is higher than Johor Bahru. It indicates that, Gua Musang has a high potential to expand the EBN productivity more advanced even though they utilize less inputs than Johor Bahru. This can also due to environmental factors such as abundant of forests, rivers and oil palm estates that attract more population of swiftlet in Gua Musang. If swiftlet houses in Gua Musang operate at the correct scale of operations, it is bright opportunity for them to have better production of EBN. Furthermore, this study find that the swiftlet ranching in Johor Bahru were relatively more efficient than in Gua Musang. For further research, this study could be further extended to investigate changes in inputs or cost, allocative and technical efficiencies over time. Finally, future research could include more variables and larger sampling size.

\section{Acknowledgement}

This study is supported by a grant from Universiti Teknologi MARA (UiTM) Cawangan Johor. Geran Penyelidikan Bestari Fasa 2/2020, Rujukan: 600-UiTMCJ (PJIA. 5/2).

\section{References}

Abdulai, A., \& Eberlin, R. (2001). Technical efficiency during economic reform in Nicaragua: evidence from farm household survey data. Economic systems, 25(2), 113-125..

Ali, M., \& Flinn, J. C. (1989). Profit efficiency among Basmati rice producers in Pakistan Punjab. American journal of agricultural economics, 71(2), 303-310.

Alias, A., Poh, A. Y., Zahirah, N., \& Azizi, M. (2013). Investment in swiftlet hotels in Malaysia Does ROI compensate investment risks?. African Journal of Business Management, 7(38), 3936-3943. 
Karimov, A., Awotide, B. A., \& Amos, T. T. (2014). Production and scale efficiency of maize farming households in South-Western Nigeria. International Journal of social economics.

Banker, R. D., \& Natarajan, R. (2008). Evaluating contextual variables affecting productivity using data envelopment analysis. Operations research, 56(1), 48-58.

Barros, C. P., \& Alves, F. P. (2004). Productivity in the tourism industry. International Advances in Economic Research, 10(3), 215-225.

Bojnec, Š., \& Latruffe, L. (2008). Measures of farm business efficiency. Industrial Management \& Data Systems.

Manasakis, C., Apostolakis, A., \& Datseris, G. (2013). Using data envelopment analysis to measure hotel efficiency in Crete. International Journal of Contemporary Hospitality Management.

Charnes, A., Cooper, W. W., \& Rhodes, E. (1978). Measuring the efficiency of decision making units. European journal of operational research, 2(6), 429-444.

Cooper, W. W., Seiford, L. M., \& Zhu, J. (2011). Data envelopment analysis: History, models, and interpretations. In Handbook on data envelopment analysis (pp. 1-39). Springer, Boston, MA.

Yen, F. L., \& Othman, M. (2011). Data envelopment analysis to measure efficiency of hotels in Malaysia. SEGi Review, 4(1), 25-36.

Golany, B., \& Roll, Y. (1989). An application procedure for DEA. Omega, 17(3), 237-250.

Hameed. (2007). Bird's Nest Industry. Malaysian Swiftlet Farming Industry Report 2007. Retrieved from http://birdsnestindustry.blogspot.my/2007/11/malaysian-swiftletfarming-industry.html.

Ibrahim, S. H., Teo, W. C., \& Baharun, A. (2009). A study on suitable habitat for swiftlet farming. Journal of Civil Engineering, Science and Technology, 1(1), 1-7.

Khoshroo, A., Mulwa, R., Emrouznejad, A., \& Arabi, B. (2013). A non-parametric Data Enveopment Analysis approach for improving energy efficiency of grape production. Energy, 63, 189-194.

Wang, L., Huo, X., \& Kabir, S. (2013). Technical and cost efficiency of rural household apple production. China Agricultural Economic Review.

Lim, C. (2007). Make Millions From Swiftlet Farming: a Definitive Guide. Kuala Lumpur: True Wealth Publishing. ISBN: 978-983-3364-25-1.

Shahwahid, M., \& Zulnaidah. (2012). An economic analysis of swiftlet edible bird's nest industry. Kuala Lumpur. Forestry Department Peninsular Malaysia.

Omid, M., Ghojabeige, F., Delshad, M., \& Ahmadi, H. (2011). Energy use pattern and benchmarking of selected greenhouses in Iran using data envelopment analysis. Energy conversion and management, 52(1), 153-162.

Ramanathan, R. (2003). An introduction to data envelopment analysis: a tool for performance measurement. Sage.

Sotnikov, S. (1998). Evaluating the effects of price and trade liberalisation on the technical efficiency of agricultural production in a transition economy: The case of Russia. European Review of Agricultural Economics, 25(3), 412-431.

Stefanou, S. E., \& Saxena, S. (1988). Education, experience, and allocative efficiency: a dual approach. American Journal of Agricultural Economics, 70(2), 338-345.

Thanassoulis, E. (2001). Introduction to the theory and application of data envelopment analysis. Dordrecht: Kluwer Academic Publishers. 
INTERNATIONAL JOURNAL OF ACADEMIC RESEARCH IN BUSINESS AND SOCIAL SCIENCES

Vol. 12, No. 1, 2022, E-ISSN: 2222-6990 @ 2022 HRMARS

Wollni, M., \& Brümmer, B. (2012). Productive efficiency of specialty and conventional coffee farmers in Costa Rica: Accounting for technological heterogeneity and selfselection. Food Policy, 37(1), 67-76. 